\title{
MARSZALEK WIELKI KORONNY STANISLAW HERAKLIUSZ LUBOMIRSKI WOBEC SEJMU 1683 ROKU I PROBLEMU WOJNY Z PORTĄ OSMAŃSKĄ
}

Stanisław Herakliusz Lubomirski (ur. I642, według niektórych I64I) był jednym z najwybitniejszych przedstawicieli doby polskiego baroku. Kolejne pokolenia historyków, podkreślały jego talenty oratorskie, pisarskie, niepospolity umysł oraz działalność na polu kulturalnym. W mniejszym stopniu doceniały natomiast talenty polityczne marszałka ${ }^{\mathrm{I}}$, przez co wprowadzony do obiegu naukowego obraz S.H. Lubomirskiego nadal wymaga wielu uzupełnień oraz korekt - pomijając już fakt, że jego osoba wciąż nie doczekała się kompleksowej biografii ${ }^{2}$. Niniejsze studium stanowi zatem próbę poszerzenia dotychczasowego stanu wiedzy, a przedmiotem badań będzie postawa Lubomirskiego wobec sejmu I683 r. i rozpatrywanego na nim problemu zagrożenia tureckiego.

Rolę działalności politycznej S.H. Lubomirskiego docenili już Wanda Roszkowska z Krystynem Matwijowskim, Józef Andrzej Gierowski czy Agnieszka Skórska-Jarmusz, ale chyba dopiero badania Krzysztofa Wiśniewskiego pozwoliły zrozumieć, na czym polegała jej specyfika3. S.H. Lubomirski na sejmie koronacyjnym Jana III w lutym i676 r. otrzymał laskę wielką koronną - po trzyletnim okresie piastowania urzędu marszałka nadwornego

* Dr Zbigniew Hundert - zainteresowania badawcze: polityczna, wojskowa i ekonomiczna historia Rzeczypospolitej w drugiej połowie XVII wieku. E-mail: zb.hundert@gmail.com.

1 Reprezentatywna jest tu opinia biografa młodszego brata marszałka - Hieronima Augustyna Lubomirskiego, że Stanisław Herakliusz ,nie posiadał większych zdolności politycznych i często ulegał wpływom swego brata Hieronima". Obraz ten nie wytrzymuje w konfrontacji z najnowszymi badaniami; zob. K. Piwarski, Hieronim Lubomirski. Hetman wielki koronny, Oświęcim 2015 (reedycja wydania z 1929 r.), s. 10; por. Z. Hundert, Działalność wojskowa i polityczna Hieronima Augustyna Lubomirskiego w latach 1669-1673 - glosa do biografii, w: Hortus bellicus. Studia z dziejów wojskowości nowożytnej, red. K. Bobiatyński, P. Gawron, K. Kossarzecki, D. Milewski, P. Kroll, „Biblioteka Epoki Nowożytnej”, 5/2017, s. 387.

2 Wypada się tu zgodzić z Krystyną Stasiewicz, że kompleksowe opracowanie tej postaci to poważne wyzwanie, ponieważ „napisanie biografii tak wybitnej, ale i kontrowersyjnej osobistości obdarzonej wieloma talentami (politycznym, mecenasowskim, pisarskim) wymaga współpracy historyków, filologów, historyków sztuki i filozofii”; zob. eadem, W kręgu polityki i literatury: źródła i studia o Stanisławie Herakliuszu Lubomirskim, Olsztyn 2016, s. 6. Niemniej, polityczna biografia marszałka już powstała - w 2004 r. w Krakowie została obroniona praca doktorska Agnieszki Skórskiej-Jarmusz pt. Stanisław Herakliusz Lubomirski (1641-1702). Nie ukazała się jednak drukiem, poza fragmentem, poświęconym powinnościom Lubomirskiego, jako starosty spiskiego; zob. eadem, Stanisław Herakliusz Lubomirski - starosta spiski, „Rocznik Sądecki”, 34/2006, s. 62-86.

3 K. Matwijowski, W. Roszkowska, Lubomirski Stanisław Herakliusz (ok. 1642-1702), w: Polski Stownik Biograficzny (dalej: PSB), t. 18, Wrocław 1973, s. 45-50; J.A. Gierowski, Stanisław Herakliusz Lubomirski jako polityk, w: Stanisław Herakliusz Lubomirski. Pisarz - polityk - mecenas, red. W. Roszkowska, Wrocław - Łódź 1982, s. 9-24; A. Skórska-Jarmusz, Stanisław Herakliusz Lubomirski - starosta spiski, s. 86; K. Wiśniewski, Działalność marszałka wielkiego koronnego Stanisława Herakliusza Lubomirskiego w bezkrólewiu po śmierci Jana III, 
koronnego. Tym sposobem w wieku zaledwie 33 lat (rocznikowo 34) sięgnął po najwyższy urząd ministerialny w Koronie - urząd, który ongiś sprawował jego ojciec Jerzy Sebastian (w latach I650-I664). Stanisław Herakliusz był jedną z sześciu osób, które w XVII w. piastowały godność marszałka wielkiego - i spośród nich był najdłużej wykonującym te powinności, bo 26 lat (zmarł w początkach I702 r.) Do końca istnienia polskiej państwowości u schyłku XVIII stulecia, tylko Jerzy Mniszech dłużej pozostawał od Lubomirskiego na urzędzie marszałka wielkiego (od I7I3 r. przez okres 29 lat)4. Już sama długość sprawowania tego istotnego urzędu, obłożonego dużą ilością obowiązków, a przynoszącego wymierne korzyści dopiero po zainwestowaniu w niego czasu, pieniędzy i ciężkiej pracy5, powinna skłonić do refleksji. Jak dowodzą wspomniane wyżej badania K. Wiśniewskiego, to właśnie laska wielka koronna była źródłem siły politycznej Lubomirskiego, ponieważ: „Po raz pierwszy urząd marszałkowski objął magnat, świetnie orientujący się w zasadach, jakie obowiązywały w zaczynającym już bezwzględnie dominować systemie fakcyjnym, i jego wyznawca. W przeciwieństwie do swego ojca Stanisław Herakliusz Lubomirski nie absentował się od dworu i jak nikt przed nim potrafił wykorzystać prerogatywy urzędu marszałkowskiego do prowadzenia własnej polityki, często działając na granicy prawa"6. Jest to bardzo cenna uwaga, która znajduje potwierdzenie w aktualnych badaniach nad epoką Jana III Sobieskiego.

W I683 r. mijał ıo rok, od kiedy Lubomirski otrzymał laskę koronną, i od kiedy - z pewnymi przerwami - faktycznie prowadził urząd marszałkowski . Już wówczas był świetnie zorientowany w funkcjonowaniu swojego ministerium ${ }^{8}$, co ilustruje jego rzeczowa i merytoryczna odpowiedź na list z sejmiku województwa sandomierskiego z września I683 r. Nadawca pisma - marszałek sejmiku opatowskiego, wojewodzic ruski Przecław Lanckoroński, wzywał Lubomirskiego, aby „urzędu swego zażyć raczył” w sprawie zatrzymania podskarbiego koronnego Jana Andrzeja Morsztyna, który zamierzał opuścić Rzeczpospolitą wskutek ujawnienia na sejmie I683 r. jego antykrólewskiej działalności. Pomijając aspekt

„Rocznik Warszawski”, 30/2001, s. 13-52; idem, Urzad marszałkowski koronny w bezkrólewiach XVII-XVIII wieku (1632-1736), Warszawa 2015, s. 111.

4 Zob. Urzędnicy dawnej Rzeczypospolitej XII-XVIII wieku. Spisy, red. A. Gąsiorowski, t. 10: Urzędnicy centralni i nadworni Polski XIV-XVIII wieku. Spisy, oprac. K. Chłapowski et al., Kórnik 1992, s. 80-81.

5 Zob. K. Wiśniewski, Urząd marszałkowski koronny..., s. 402-404.

6 Ibidem, s. 111; por. idem, Działalność marszałka..., s. 13-14.

7 Już niebawem po otrzymaniu laski nadwornej w 1673 r. stanął na czele urzędu marszałkowskiego, gdy ówczesny marszałek wielki J. Sobieski był zajęty powinnościami hetmańskimi. Lubomirski przypomniał o tym w liście do brata z 1686 r.; zob. S.H. Lubomirski do H.A. Lubomirskiego, Jazdów, 8 VIII 1686, Biblioteka Polskiej Akademii Umiejętności i Polskiej Akademii Nauk w Krakowie (dalej: B. PAU/PAN Kraków), rkps 1077, s. 201-203; K. Wiśniewski, Urząd marszałkowski koronny..., s. 391. Z racji, że w 1670 r., jako marszałek sejmu, doprowadził do pomyślnego zakończenia obrad, Michał Korybut wyniósł go do godności marszałka nadwornego po zmarłym na początku 1673 r. Janie Klemensie Branickim; zob. L.A. Wierzbicki, O zgodę w Rzeczypospolitej. Zjazd warszawski i sejm pacyfikacyjny 1673 roku, Lublin 2005, s. 152, 193, 198-200.

8 Należy rozgraniczać urząd marszałka wielkiego koronnego od urzędu marszałkowskiego. Minister ten mógł korzystać ze swoich prerogatyw tylko wówczas, gdy znajdował się u boku królewskiego. W razie gdyby go nie było, na czele urzędu marszałkowskiego stawał inny z marszałków, a w przypadku i ich absencji - któryś z pozostałych ministrów, według rangi zasiadania w senacie. Sam Lubomirski pisał w 1686 r. do swego brata Hieronima Augustyna, że „marszałkowski urząd zawiera w sobie wszystkich marszałków nie tylko jednego marszałka, po tym dopiero pięczętarze i podskarbiowie supplent vices absentium kiedy by żadnego z nich nie było. Są na to diploma speciala w Metryce Koronnej"; S.H. Lubomirski do H.A. Lubomirskiego, Jazdów, 8 VIII 1686, B. PAU/PAN Kraków, rkps 1077, s. 202; K. Wiśniewski, Urząd marszałkowski koronny..., s. 391. 
politycznych związków marszałka wielkiego z Morsztynem - o czym będzie dalej - Lubomirski nie mógł spełnić prośby, albowiem - jak zapisał - ,przy boku JKM zostając praesens powinienem tylko sądzić causas criminum et facti i captivare takowe osoby, które pod bokiem JKM zostają, i które są tylko iure victi: nie będąc zaś przytomnym u JKM, exequitur jurysdykcyję moję marszałek nadworny, a na miejscu marszałków subsequentes urzędnicy ordine suo w senacie zasiadający; tak dalece, że urząd marszałkowski i executio jego zawsze jest przy boku JKM przytomna, lubo którego z marszałków nie masz. Marszałek zaś kiedy jest absens ode dworu i mieszka po województwach prywatnie, pro privato też censet" . We wrześniu I683 r. król na czele wojsk koronnych znajdował się na terenie Cesarstwa, toteż przebywający w Polsce Lubomirski nie mógł sprawować powinności urzędu - i był tego dobrze świadom, co dowodzą kolejne wersy jego odpowiedzi Lanckorońskiemu. Inna sprawa, że powołanie się tu na aspekty formalno-prawne było dla marszałka wielkiego dość wygodne, ze względu na jego wcześniejsze, zażyłe kontakty polityczne z Morsztynem ${ }^{\mathrm{I0}}$.

Jak utarło się w polskiej historiografii, Lubomirski miał w I68I r. (a w zasadzie na przełomie lat 70. i 8o.) przejść do opozycji - i trwać w niej do śmierci Jana III - aczkolwiek jeszcze J.A. Gierowski zauważył, że takie stwierdzenie jest uproszczeniem, ponieważ istniały momenty poprawnej współpracy króla ze Stanisławem Herakliuszem ${ }^{\text {II }}$. Aspekt przejścia do opozycji zaważył na samym postrzeganiu Lubomirskiego jako marszałka, co potwierdza uwaga zawarta w pamiętnikach kawalera de Beaujeu: „Zdarzyło się raz, że w dniu Bożego Ciała I680 r. król znajdował się w Warszawie w kościele św. Jana bez laski, gdyż wielki marszałek będąc wówczas poróżniony z dworem, zaniedbał uczestniczyć w owej ceremonii lub przysłać za siebie następcy. Wielki kanclerz [Jan Wielopolski] również cierpiał na podagrę, tak, że król nie wiedział do kogo się zwrócić, by urząd ów miał przedstawiciela. Wysłał przeto dwukrotnie jednego z dworzan do wielkiego marszałka z rozkazem przybycia. Na pierwsze wezwanie marszałek dał wymijająca odpowiedź, lecz na powtórne naleganie polecił odpowiedzieć królowi, aby sobie przypomniał, że będąc sam wielkim marszałkiem, za panowania króla Michała, nie lepiej pełnił swą powinność"'2 . Wydaje się jednak, że opisane zdarzenie miało raczej charakter incydentalny, a Lubomirski wypełniał swoje obowiązki starannie - jak uważa Jarosław Stolicki³. W końcu mógł on w pełni wykorzystywać urząd marszałkowski do swej działalności politycznej dopiero wówczas, gdy przebywał przy dworze. Stąd w okresie poprzedzającym ekspedycję przedsejmową w I682 r. widoczna jest

\footnotetext{
9 P. Lanckoroński do S.H. Lubomirskiego, Opatów, 13 IX 1683 i odpowiedź na ten list z 23 IX 1683, B. PAU/ PAN Kraków, rkps 1077, s. 45-49, w innych kopiach: Львівська Національна Наукова Бібліотека України імені Василя Стефаника [dalej: ЛННБУ], F. 141 (Zbiór Czołowskiego), op. 1, rkps 53, s. 43-47. Wydaje się, że Lubomirski list Lanckorońskiego, wraz ze swoją odpowiedzią, kolportował w formie pism politycznych w celach propagandowych.

10 Tak rozumiał list Lubomirskiego J.A. Gierowski (op. cit., s. 18). W jego opinii marszałek, mimo nacisków społecznych, nie chciał (a nie nie mógł) aresztować Morsztyna.

11 J.A. Gierowski, op. cit., s. 17; por. K. Matwijowski, W. Roszkowska, op. cit., s. 47; K. Wiśniewski, Urząd marszatkowski koronny..., s. 111.

12 Pamiętniki kawalera de Beaujeu, thum. A. Kraushar, oprac. W. Markowski, Kraków 1883, s. 205; K. Wiśniewski, Urząd marszałkowski koronny..., s. 198. Autorem cytowanych pamiętników, według historiograficznej tradycji, miał być dworzanin Jana III - Françoise Paulin Dalerac. Zgodnie z obecnym stanem wiedzy nie jest to takie oczywiste.

13 J. Stolicki, Rozdawnictwo wakansów przez Jana III jako metoda tworzenia partii dworskiej, w: Faworyci i opozycjoniści. Król a elity polityczne w Rzeczypospolitej XV-XVII wieku, red. R. Skowron, M. Markiewicz, Kraków 2006, s. 367.
} 
obecność marszałka na dwóch dość ważnych radach senatu po zerwanym sejmie I68I r. ${ }^{\mathrm{I}}$. Niewątpliwie w przededniu sejmu, na którym decydować się miała sprawa sojuszu z Cesarstwem i wojny z Portą, Lubomirski należał do pierwszoplanowych postaci polskiej sceny politycznej, dlatego nie mógł być pomijany w jakichkolwiek grach i układach.

Program dworu królewskiego, jako forma reakcji na dynamiczne zmiany polityczne w sąsiedztwie Rzeczypospolitej, został zainicjowany w sierpniu I682 r. listami deliberatoryjnymi do senatorów - na razie jeszcze bez wskazania propozycji zwołania sejmu. Król prosił w deliberatoriach o ustosunkowanie się panów rady do rozruchów w Państwie Moskiewskim i osadzenia na stolcu hospodarskim dwóch carewiczów: Piotra i Iwana, wskazując na panujący za wschodnią granicą chaos ${ }^{15}$. Następnie poddał uwadze wydarzenia dokonujące się na Górnych Węgrzech, czyli powstanie kuruców przeciwko władzy Habsburgów, akcentując zajęcie Koszyc, uzyskanie przez rebeliantów pomocy osmańskiej, zagrożenie miast spiskich i w konsekwencji zagrożenie graniczącego ze Słowacją województwa krakowskiego z miastem stołecznym ${ }^{16}$. Lubomirski nie mógł być tu obojętny, ponieważ narażone na działania kuruców i wspierających ich Turków starostwo spiskie należało do marszałka wielkiego i stanowiło jego ważne zaplecze materialne ${ }^{\mathrm{I} 7}$.

Miesiąc później, 30 września, król wystosował deliberatoria z propozycją zwołania sejmu, a gdy odebrał „responsa od wielmożnych senatorów na duplikaty swoich odezw”, 4 listopada rozesłał uniwersały do sejmików. Początek obrad sejmowych został wyznaczony na 27 stycznia I683 r. w Warszawie. Jan III w swoim uniwersale kładł nacisk „,na sąsiedzką od Krakowa rewolucyją, i to, że jako całemu Chrześcijaństwu portentosus nieprzyjaciel znowu na wojnę arma virosque parat". Informował ponadto, że zajęcie Górnych Węgier przez kuruców - od niedawna lenników tureckich, poskutkuje rozciągnięciem obszaru występowania zagrożenia osmańskiego z pogranicza podolsko-halickiego do granic województwa krakowskiego ze Słowacją i Śląskiem ${ }^{18}$. W ten sposób król w swojej ekspedycji sejmowej promował już wyłącznie antyturecki kierunek polityki dworu.

Zanim wystosowano legację na sejmiki, król odebrał wspomniane wyżej odezwy senatorów, w tym tę nadaną przez S.H. Lubomirskiego. Odpowiedź marszałka wielkiego na

14 Zob. Senatus consilium post comitiale, Warszawa, 9 VI 1681, Archiwum Główne Akt Dawnych w Warszawie (dalej: AGAD), Archiwum Zamoyskich (dalej: AZ), sygn. 3046, s. 265-271; Senatus consilium, Warszawa 31 V 1681, ibidem, s. 272.

15 Więcej zob. K. Koczegarow, Rzeczpospolita a Rosja w latach 1680-1686. Zawarcie traktatu o pokoju wieczystym, thumaczenie z j. rosyjskiego, wyd. uzup. i popr., red. T. Szwaciński, Warszawa 2017, s. 129-189.

16 Literae Regis deliberatoriae ad senatores, Jaworów, 22 VIII 1682, w: Akta do dziejów króla Jana III sprawy roku 1683, a osobliwie wyprawy wiedeńskiej wyjaśniające, oprac. F. Kluczycki, Kraków 1883, s. 1-4; por. J. Wimmer, Wiedeń 1683. Dzieje kampanii oraz bitwy, Warszawa 1983, s. 125-129.

17 Lubomirski został starostą spiskim w 1660 r. w wyniku cesji starostwa przez ojca. Więcej zob. A. Skórska-Jarmusz, Stanisław Herakliusz Lubomirski - starosta spiski, s. 62-86. Zob. też Stanistawa Herakliusza Lubomirskiego mowy sejmowe z 1670 i 1673 roku oraz „Informacyja potrzebna bardzo Rzeczypospolitej 1671 o prawie wlasnym i dziedzicznym, które ma Rzeczpospolita do Spisza i części ziemie węgierskiej, przeciwko pretensyjom Cesarza JM, tudzież jako wiele Rzeczypospolitej należy na utrzymaniu tego kraju”, oprac. K. Przyboś, red. A. Perłakowski, Kraków 2010, s. XXVII-XXXV (wstęp K. Przybosia).

18 Instrukcyja JKM na sejmiki przedsejmowe sejmu warszawskiego na d. 27 januarii a. 1683 naznaczonego, [4 XI 1682], w: Akta do dziejów..., s. 5-10 (stąd cytaty); R. Kołodziej, „Ostatni wolności naszej klejnot”. Sejm Rzeczypospolitej za panowania Jana III Sobieskiego, Poznań 2014, s. 16, 21-22; por. K. Konarski, Polska przed odsiecza wiedeńska 1683 roku, Oświęcim 2017 (reedycja wydania z 1914 r.), s. 104-105; J. Wimmer, Wiedeń 1683..., s. 131-132; J. Stolicki, Wobec wolności i króla. Działalność polityczna szlachty ruskiej, ukrainnej $i$ wolyńskiej w latach 1673-1683, Kraków 2007, s. 244-245. 
królewski list deliberatoryjny zachowała się przynajmniej w dwóch kopiach - które, jak dowiodła krytyka, różnią się od siebie w kwestii zasadniczej, tj. w stosunku do polityki zagranicznej. Pierwsza z odezw zachowała się w Archiwum Zamoyskich - razem z dwudziestoma sześcioma innymi odpowiedziami senatorów na listy królewskie; druga natomiast została zamieszczona w kopiariuszu z materiałami dotyczącymi działalności S.H. Lubomirskiego ${ }^{19}$. Ich analiza będzie stanowić pierwszy etap rozważań na temat stosunku marszałka wielkiego do sejmu I683 r.

Przemożną część odpowiedzi Lubomirskiego zajęły propozycje usprawnienia obrad sejmowych. Była to istotna kwestia zważywszy na doświadczenia poprzedniego sejmu z I68I r. - który był najdłuższym posiedzeniem w dobie panowania Jana III, a ostatecznie został zerwany, pierwszy raz po objęciu tronu przez Sobieskiego. Na początku marszałek wielki uznał, że „niepewność bezpieczeństwa stoi za samo niebezpieczeństwo”, dlatego sejm należy zwołać, a co do jego terminu nie może mieć żadnych zastrzeżeń, bo ten zależy od decyzji królewskiej. Propozycje Lubomirskiego skupiły się wokół kwestii, ,żeby sejmy w tak długie nie szły prolongacyje i aby more antiquo stawały i kończyły się”. Ten aspekt pozostawił zresztą sejmikom, aby to one wypracowały odpowiednie mechanizmy. Zgadzał się na zapłacenie chanowi pensji (czyli tzw. upominków tatarskich), zaległości wojsku oraz na zebranie środków przez „lekki a ustawiczny podatek” na przyszłe potrzeby. Uznał, że będzie to pewien paradoks, gdyby Rzeczpospolita miała swoje zapasy budżetowe, ale może mieć tu ,exemplo innych państw, byle cnota była, ta zaś być może, gdy będzie sprawiedliwość et rigor przy prawie". W następnej części swojej odpowiedzi kładł nacisk na utajnienie części obrad sejmowych, jak propozycje od tronu czy wota senatorskie, „, bo z tego sequitur mora niepotrzebna sejmu, że sentencyja in publico nie bywają tylko pro forma metu divulgationis a siła czasu biorą i cały senat chowa się na przymawianie, które po tym distrahitur głosami a in votis nic esentiale nie traktuje się". Lubomirski w związku z tym proponował, aby od przedstawienia tzw. propozycji od tronu aż do końca sejmu wszystkie narady odbywały się bez świadków - co województwa powinny zalecić w instrukcjach dla swoich posłów ${ }^{20}$.

W kwestii ustosunkowania się do kierunku polityki zagranicznej pierwsze zdania dwóch znanych wersji odezwy Lubomirskiego zawierają te same uwagi. Marszałek radził w propozycji od tronu odnotować tylko sprawy „o rzeczach i koniunkturach moskiewskich liberius, niż o tureckich - i następnie, aby województwa o koniunkturach tamecznych mogły być informowane". Wyraził przy tym swoje nadzieje, że wojny może nie być, licząc że Porta podejmie inny kierunek uderzenia niż Rzeczpospolita. Przy tym uznał, że nie godziłoby się państwu nie utrzymywać siły zbrojnej - ale utrzymywanie jej bez wojny - uznał z kolei za daremną szkodęę. Jak zatem widać - już z tych zapisów jasno wynika, że Lubomirski był sceptyczny wobec wojny tureckiej.

\footnotetext{
19 Odpowiedź S.H. Lubomirskiego na deliberatorium, Warszawa, 21 X 1682, AGAD, AZ, sygn. 3046, s. 318-320; Respons od króla jmści na deliberatotorias przez jmp. marszałka w. koron., B. PAU/PAN Kraków, rkps 1077, s. 31-34. Skrótowa analiza tego i pozostałych odpowiedzi na deliberatoria z 1682 r.: R. Kołodziej, ,, Ostatni wolności ..., s. 26-28.

20 Odpowiedź S.H. Lubomirskiego na deliberatorium, Warszawa, 21 X 1682, AGAD, AZ, sygn. 3046, s. 318-319 (stąd cytaty); Respons od króla jmści na deliberatotorias przez jmp. marszatka w. koron., B. PAU/PAN Kraków, rkps 1077, s. 31-33. Kilka propozycji Lubomirskiego w kwestiach procedury sejmowej omawia w różnych miejscach swojej pracy Robert Kołodziej (,, Ostatni wolności..., s. 27-28, 156, 218, 465).

${ }_{21}$ Odpowiedź S.H. Lubomirskiego na deliberatorium, Warszawa, 21 X 1682, AGAD, AZ, sygn. 3046, s. 319-320 (stąd cytaty); Respons od króla jmści na deliberatotorias przez jmp. marszałka w. koron., B. PAU/PAN Kraków, rkps 1077, s. 33.
} 
Kolejne uwagi Lubomirskiego w dwóch wersjach jego odezwy zostały sformułowane w odmienny sposób. W odpowiedzi na deliberatorium z Archiwum Zamoyskich marszałek wielki zawarł taką opinię, że „Turczyn śmielej by w długą gdzie indzi[ej] zaprzągł się wojnę, gdyby widział Polskę gdzie indzi[ej] też conatus obracającą". Radził, by być przygotowanym na dwie możliwości, ale moskiewski kierunek uderzenia („contra Septemtrionem versa”) uznał za właściwszy, bo ,aukcyją i kozackie [siły] do Polski lepszą inklinacyją przywrócone, szczęśliwej będą się mogły in orientem gotowe obrócić”. Widział zatem możliwość odzyskania kontroli nad Kozaczyzną, w tym chyba i tą zadnieprską - co w przyszłości mogłoby pozwolić na lepsze przygotowanie się do wojny z Portą. Sposób wnioskowania Lubomirskiego można zatem określić następująco: radził on załatwić najpierw sprawy moskiewskie, wykorzystując wewnętrzny chaos u wschodniego sąsiada, aby móc rewindykować straty terytorialne, usankcjonowane rozejmem andruszowskim z I667 r., a dopiero potem powrócić do kierunku antytureckiego. Marszałek radził także, żeby sejm podjął decyzje o wysłaniu poselstw - pierwszego do Stambułu, by utwierdzić Turcję, że pokój z nią zostanie utrzymany. Chciał tu zachować ostrożność i wykorzystać w rozmowach osoby trzecie (bez wątpienia miał na myśli pomoc dyplomacji francuskiej). Kolejne poselstwo radził wysłać do Moskwy, „aby się upomnieć dawnych z przeszłymi carami pakt, oddania ablatorum, i pretekst sobie powoli, in omnem occasionem nagotować z nimi do wyśliźnienia się z[e] szkodliwych lat przymiernych, kiedy by się potrzebna do tego koniunktura podała". Przy okazji zawarł uwagę, że nie zaszkodzi, gdy wyśle się też poselstwo do chana krymskiego, ,aby go do ściślejszej przyjaźni obligować wyrozumieć i utwierdzić jako najlepiej”. Jak widać, marszałek wielki obrał tu wyraźny kierunek antymoskiewski ${ }^{22}$.

W drugiej wersji odezwy Lubomirski również wyraził stanowisko antymoskiewskie, aczkolwiek w sposób bardziej wyważony. Z jednej strony wskazywał na słuszność ofensywy w kierunku wschodnim: ,preparowawszy rzeczy w Moskwie, progres tam uczynić, ablata odebrać, siły Rzptej augere per acqvisitionem terrarum i dopiero o wojnie tureckiej gruntownie myśleć"; z drugiej wskazywał na możliwość stworzenia trójprzymierza (na linii Moskwa - Warszawa - Wiedeń) i uderzenia na Portę. Uznał, że czas pokaże, który kierunek działań będzie trzeba realizować - z tym, że powinno się być przygotowanym na obie ewentualności. W tej wersji odezwy Lubomirski zwrócił pokrótce uwagę na sytuację na Górnych Węgrzech, czego już np. nie uczynił w wersji poprzedniej; w zamian pominął sprawę poselstw ${ }^{23}$. Na obecnym etapie badań można uznać, że pierwsza wersja została dostarczona królowi - druga, w której marszałek zdecydowanie łagodniej odnosił się do problemów, mających wyraźne poparcie społeczne (polityka antyturecka) ${ }^{24}$, otrzymała charakter pisma politycznego i została przeznaczona do wiadomości opinii publicznej. Niewykluczone też, że powstała później.

Trudno jednoznacznie stwierdzić, czy wszystkie opinie Lubomirskiego wynikały z jego osobistych odczuć i przemyśleń, czy też może wyrażały stanowisko jego politycznego

\footnotetext{
${ }_{22}$ Odpowiedź S.H. Lubomirskiego na deliberatorium, Warszawa, 21 X 1682, AGAD, AZ, sygn. 3046, s. 320; K. Koczegarow, op. cit., s. 187.

${ }^{23}$ Respons od króla jmści na deliberatotorias przez jmp. marszalka w. koron., B. PAU/PAN Kraków, rkps 1077, s. 33-34.

24 Poważny wpływ na to miała prowadzona przez dwór antyturecka akcja propagandowa; zob. J. Stolicki, Propaganda antyturecka w latach 1676-1683, w: Król Jan III Sobieski i Rzeczpospolita w latach 1674-1683, red. D. Milewski, Warszawa 2016, s. 19-33.
} 
środowiska. Nie ma bowiem wątpliwości, że obranie bardziej aktywnego kierunku wschodniego (który w I682 r. był zresztą realizowany - m.in. poprzez próbę wywołania antymoskiewskiego powstania na Lewobrzeżu ${ }^{25}$ ) było po myśli Francji, która nie chciała, aby Rzeczpospolita wsparła cesarza przeciwko Porcie Osmańskiej. Jak zauważył Kirył Koczegarow, który szerzej analizował pod kątem stosunków polsko-moskiewskich responsy na deliberatoria królewskie z ekspedycji przed sejmem I683 r., niewielu senatorów nawiązywało do problemu wschodniego sąsiada, skupiając się przede wszystkim na kwestiach zagrożenia tureckiego ${ }^{26}$. Z bardziej wpływowych polityków, których odpowiedzi są znane, tylko podskarbi Morsztyn i wojewoda poznański Krzysztof Grzymułtowski byli ewidentnie przeciw wojnie z Portą. Wprawdzie podskarbi wielki nie sugerował kierunku moskiewskiego, ale ten drugi już tak, pisząc: „Portę do czasu głaskać a ozwać się do rekuperowania ablatorum od Moskwy, przy tak dobrej jako Pan Bóg podaje okazji’”27. Grzymułtowski i Morsztyn, jak już dawno dowiedziono w polskiej historiografii, należeli od kilkunastu lat do sympatyków Francji i wraz z porzuceniem przez króla polityki profrancuskiej (w I679 r.), ich drogi z Janem III się rozeszły. Lubomirski, przedstawiając takie poglądy, jak wyżej, wpisywał się zatem w ogólną retorykę profrancuskiej opozycji, którą de facto współtworzył. Zresztą swój stosunek do spraw międzynarodowych wyraził dobitnie I3 listopada I682 r. w liście do jednego z głównych współpracowników króla, księdza podkanclerzego koronnego Jana Gnińskiego: „Nie wiem jeżeliś WMMM Pan widział mój list na deliberatorias odpisany; podaję tam media, aby go prędzej skończyć, co daj Panie Boże, abyśmy go tak traktowali, żebyśmy Turczyna nie zaprosili na wstęp i nie wywołali (ut aiunt) wilka z lasa. Abyśmy przez jakie traktaty z cesarzem nie wdawali się in periculum własnego grzbieta. Moskwicina abyśmy choć zraz też (jako on nas) dobrze odrwili, papieża zawsze chwalili i szanowali, Francuza nigdy nie gniewali, Brandenburczyka mało straszyli, a nic nie zaczepiali, Szwedom nigdy nie wierzyli, z Austriaków też przez drugich obalonych raczej się pożywili niżeli dla nich uwikłali”28. Wyrażone tu poglądy bezapelacyjnie lokują marszałka wielkiego w gronie przeciwników sojuszu z cesarzem i wojny z Portą, a więc i przeciwników politycznych obozu dworskiego ${ }^{29}$. W związku z tym marszałek wielki mógł być podczas sejmu - zważywszy na uprawnienia urzędu - poważnym zagrożeniem dla króla chcącego przedsięwziąć stanowcze kroki, aby podjąć zbrojną rozprawę przeciw Imperium Osmańskiemu.

Dwór królewski bardzo starannie przygotował się do sejmu, co dowodzi zdobycie sobie wpływu na tak ważny sejmik jak zjazd województwa krakowskiego obradujący w Proszowicach. Jeden z najważniejszych politycznych i wojskowych współpracowników króla kasztelan krakowski Andrzej (Jędrzej) Potocki - pisał do podczaszego wiskiego Stanisława Antoniego Szczuki 2I grudnia I682 r.: „Lubo zaś z wielkim niewczasem i fatygą w dzień

\footnotetext{
25 K. Koczegarow, op. cit., s. 137-174; P. Kroll, Jan III Sobieski wobec Kozaczyzny w latach 1676-1683, w: Król Jan III Sobieski..., s. 217-226.

${ }^{26}$ K. Koczegarow, op. cit., s. 186-187.

27 Zob. Odpowiedź na deliberatorium K. Grzymułtowskiego, w Stempuchowie, 18 X 1682, AGAD, AZ, sygn. 3046, s. 309-310; Odpowiedź na deliberatorium J.A. Morsztyna, 28 X 1682, ibidem, s. 350.

28 S.H. Lubomirskiego do J. Gnińskiego, 13 XI 1682, B. PAU/PAN Kraków, rkps 1077, s. 19; por. K. Konarski, op. cit., s. 109; A. Skórska-Jarmusz, Stanisław Herakliusz Lubomirski-starosta spiski, s. 72. O roli Gnińskiego w polityce Jana III zob. A. Przyboś, Gniński Jan (zm. 1685), w: PSB, t. 8, Kraków 1959, s. 149-151.

${ }_{29}$ Kazimierz Konarski (op. cit., s. 107) podkreślił, że Lubomirski był postrzegany jako jeden z przywódców obozu francuskiego w Polsce.
} 
sam sejmiku zbieżałem, tego nie żałuję, bo z łaski Bożej szczęśliwie pod dyrekcyją jmp. chorążego koronnego [Hieronima Augustyna Lubomirskiego] ad mentem propozycjej w instrukcjej JKM wyrażonych sejmik stanął”. Po wymienieniu kompletu wybranych na sejm posłów - który miał w pełni odpowiadać dworowi królewskiemu, Potocki stwierdził, że tak pomyślny przebieg sejmiku to efekt jego bytności w Proszowicach ${ }^{30}$. Jak widać, pozasystemowe mechanizmy oddziaływania na sejmiki, w tym przypadku na sejmik „górnego" województwa, stanowiły ważny element strategii sejmowej, aczkolwiek potrzebne są na ten temat kolejne badania ${ }^{31}$. S.H. Lubomirski, z racji obsadzenia urzędu marszałkowskiego przedstawicielami szlachty warszawskiej (urząd ten funkcjonował głównie w Warszawie), doprowadził do pacyfikacji tradycyjnych, antymarszałkowskich nastrojów Warszawian i zyskał na Mazowszu ogromną popularność, która przełożyła się na jego wpływy polityczne ${ }^{2}$. W związku z tym można domniemywać, że marszałek wielki w kampanii przedsejmowej chciał uzyskać wpływ m.in. na sejmik ziemi warszawskiej. Lektura instrukcji tego zjazdu szlacheckiego może potwierdzić wyrażony pogląd. Pierwszym z dwóch posłów ziemi warszawskiej na sejm I683 r. został wybrany urzędnik Lubomirskiego - sędzia marszałkowski koronny (oraz podstoli warszawski) Jan Kazimierz Szymanowski. Drugim był natomiast chorąży liwski Jacek Rostworowski, który pozostawał w pewnych relacjach z marszałkiem wielkim, albowiem to on, jak plenipotent, odbierał I9 maja I683 r. środki cesarskie przeznaczone na regiment pieszy S.H. Lubomirskiego ${ }^{33}$. Do tego w samej instrukcji zawarto takie postulaty: aby załoga zamku w Lubowli, „ostatniego prawie od Krakowa antemuralis”, liczyła I20 ludzi, jak dawniej, oraz żeby marszałek Lubomirski otrzymał grunty w Jazdowie (Ujazdowie) $)^{34}$. Obie sprawy można zaliczyć do gatunku prywatnych, aczkolwiek ta dotycząca załogi spiskiej Lubowli wpisywała się również w ogólną strategię obronną Rzeczypospolitej.

Sejm w Warszawie rozpoczął swoje obrady 27 stycznia I683 r. Zgodnie z kadencją powinien zakończyć się Io marca, ale został limitowany i trwał ostatecznie do I7 kwietnia. Dla Lubomirskiego czas sejmowy to nie tylko bezwzględna rywalizacja polityczna, ale także wykonywanie wielorakich powinności przypisanych urzędowi, na czele którego stał. W zakres jego kompetencji wchodziło m.in. zapewnienie bezpieczeństwa obradującym poprzez piechotę marszałkowską, względnie gwardię królewską - która winna podlegać sądom

\footnotetext{
30 A. Potocki do S.A. Szczuki, Jakubowice, 21 XII 1682, AGAD, Archiwum Publiczne Potockich (dalej: APP), sygn. 315, s. 40-41. Istotną rolę odegrał tu również marszałek sejmiku - równie ważny, jak Potocki, polityczno-wojskowy współpracownik Jana III - H.A. Lubomirski, rodzony brat opozycyjnie nastawionego do dworu Stanisława Herakliusza. Więcej na ten polityczno-wojskowego otoczenia króla w tym czasie zob. Z. Hundert, Pozycja Jana III $w$ wojsku koronnym $w$ latach 1674-1683. Utrzymanie czy też utrata wpływów wypracowanych $w$ czasie sprawowania godności hetmańskiej?, w: Król Jan III Sobieski..., s. 121-151.

31 Na pewno po myśli królewskiej przebiegały też sejmiki na Rusi Czerwonej, które stanowiły tradycyjny bastion wpływów Sobieskiego i jego polityczno-wojskowego otoczenia; zob. J. Stolicki, Wobec wolności..., s. $245-250$.

32 K. Wiśniewski, Urząd marszałkowski koronny..., s. 321.

33 Kilka lat później referendarz koronny i starosta warszawski Jan Dobrogost Krasiński uznał Rostworowskiego za klienta marszałka Lubomirskiego, który z polecenia pryncypała mógłby doprowadzić do zerwania sejmiku deputackiego województwa mazowieckiego. To wszystko dowodzi istnienia struktur politycznych marszałka na Mazowszu; zob. Potwierdzenie odbioru środków cesarskich na 280 porcji pieszych nowego zaciągu regimentu S.H. Lubomirskiego, Warszawa, 19 V 1683, AGAD, Archiwum Skarbu Koronnego (dalej: ASK), dz. V, sygn. 11, f. 216; J.D. Krasiński do S.A. Szczuki, Warszawa 8 IX 1688, AGAD, APP, sygn. 163a, t. 15, s. 987.

34 Instrukcja ziemi warszawskiej, Warszawa, 16 XII 1682, B. PAU/PAN Kraków, rkps 8348, k. 292, 295 v-296. Ważnym pracownikiem urzędu marszałkowskiego był inny „Mazur” - pisarz ziemski i grodzki warszawski oraz pisarz marszałkowski Walenty Sobolewski; zob. K. Wiśniewski, Urząd marszałkowski koronny..., s. 320.
} 
marszałkowskim, rozdział stancji osobom przybyłym na sejm, prowadzenie obrad senatu i połączonych izb, zarządzanie dworem, sprawowanie niezależnego sądownictwa, przyjmowanie zagranicznych poselstw itd. ${ }^{35}$. Na temat wielu z tych powinności, w kontekście sejmu I683 r., nie ma konkretnych informacji. Podczas poprzedniego sejmu piechota marszałkowska Lubomirskiego, miast bronić bezpieczeństwa, napadła na posłów litewskich ${ }^{36}$. W I683 r. nie odnotowano z jej udziałem podobnych incydentów. Liczyła ona Ioo porcji piechoty w trybie węgierskim (tzw. Węgrzy marszałkowscy), na czele której - jeszcze w I68I r. - stał rotmistrz marszałkowski i równocześnie stanowniczy Augustyn Mierzejewski37. Czy był on rotmistrzem oraz stanowniczym w I683 r. - tego nie wiadomo. Spośród wyżej wymienionych powinności Lubomirski w trakcie sejmu i683 r. na pewno był aktywny w kontaktach z obcą dyplomacją. W diariuszu obrad odnotowano, że zaopiekował się on Karolem Ferdynandem Waldsteinem, posłem nadzwyczajnym cesarza Leopolda I do Rzeczypospolitej. Marszałek podjął go na kolacji w Jazdowie, po której poseł przybył Io lutego do swojej stancji na Krakowskim Przedmieściu. Następnie 24 lutego, podczas audiencji Waldsteina w senacie, Lubomirski odbierał od niego list kredencyjny, a potem odpowiadał na jego wystąpienie w imieniu króla ,piękną bardzo i wymowną mową, wywodząc, że to nie nowina Orłowi Polskiemu z Orłem Imperii wieść ścisłą przyjaźń" ${ }^{8}$. Mimo profrancuskich sympatii marszałek wielki nie uchylił się, jak widać, od kontaktów z posłem, którego zadaniem było zawarcie sojuszu antyosmańskiego pomiędzy cesarzem a Rzecząpospolitą. Dał przy tym popis elokwencji, ale i kurtuazji.

Lubomirski swoją aktywność polityczną podczas sejmu wyraził również poprzez udział w wotach senatorskich, pomimo że - jak odnotował w odpowiedzi na deliberatoria królewskie - nie popierał tych wystąpień publicznych w dotychczasowej formie (ze względu na ich jawność). Wota odbywały się w dniach 5-Io lutego - z przerwami. Publiczne wystąpienia zwyczajowo rozpoczęli senatorowie duchowni, a po nich głos zabierali wojewodowie i kasztelani - w sumie I6 osób. Lubomirski występował w ostatnim dniu wotów - jako pierwszy spośród grupy sześciu ministrów: kanclerza wielkiego koronnego Jana Wielopolskiego, podkanclerzego litewskiego Dominika Mikołaja Radziwiłła, podskarbich - koronnego Morsztyna i litewskiego Benedykta Pawła Sapiehy oraz marszałka nadwornego koronnego (awansowanego już na hetmana polnego i wojewodę podolskiego) Mikołaja Hieronima Sieniawskiego ${ }^{39}$. Jak odnotowano w diariuszu sejmowym: „Po obszernym dziękczynieniu królowi jmści i wymownej in laudes jego przemowie demonstrował graviter et suaviter, że wszystkie sejmu tego circa bonus publici consilia na tem się zasadzać i fatygować powinny, żebyśmy wprzód zważyli, jakie są siły nasze, bez czego konkludować wojnę abo pokój byłoby tylko mówić siłę a nic nie czynić i dlatego radził, żeby wprzód w izbie poselskiej

\footnotetext{
35 Pamiętniki kawalera de Beaujeu..., s. 203; K. Wiśniewski, Urząd marszałkowski koronny..., passim.

36 R. Kołodziej, ,, Ostatni wolności..., s. 122, 126.

37 Asygnacja dla Augustyna z Mierzejewa Mierzejewskiego na wypłacenie 500 zł ,ratione przystastwa do posłów wielkich moskiewskich”, Warszawa, 4 I 1681, AGAD, ASK, dz. VI, sygn. 23, f. 148. W 1685 r. stanowniczym był już np. Stanisław Drozdowski; zob. R. Kołodziej, ,, Ostatni wolności..., s. 127. Więcej o stanowniczych i piechocie marszałkowskiej zob. K. Wiśniewski, Urząd marszałkowski koronny..., s. 163-165, 245-251.

38 Diariusz sejmu walnego sześćniedzielnego warszawskiego anno 1683, 27 january zaczętego, AGAD, Archiwum Warszawskie Radziwiłłów (dalej: AR), dz. II (publica), sygn. 1719, s. 19, 28. Treść całej odpowiedzi w języku łacińskim: B. PAU/PAN Kraków, rkps 1077, s. 44-45. Zob. też K. Konarski, op. cit., s. 127.

39 Diariusz sejmu..., s. 10-18; K. Konarski, op. cit., s. 124-127; J. Stolicki, Wobec wolności..., s. 251-253; R. Kołodziej, ,, Ostatni wolności..., s. 214-221, 655-664.
} 
jako może być podatków nervus rem gerendam, przystąpić potem ad secretus et sanctius consilius, jeśli nam wojna abo pokój bardziej expedit. Sękiem i jako in vicinis wchodzić w ligi. Jednakże lubo w pokoju siedzieć lubo się pewniejszego dobijać przyjdzie, że po staremu obrona fortec pogranicznych jest potrzebna, rekomendował fortyfikację zamku lubaczowskiego [sic! - lubowelskiego] na Spiszu, dedukując, że jest koniecznie potrzebna dla inkursji tak od Węgrów jako od Turczyna, Krakowa fortyfikacyją wznawiał, także nader być potrzebną, za lwowską dziękował królowi jmści. Konkludował instancją do JKM i Rzptej za sukcesorami p. Boratiniego"40.

Lubomirski w swym wotum przyjął zatem retorykę z odpowiedzi na deliberatorium królewskie, za kwestie kluczowe uznał bowiem sprawy uchwał podatkowych oraz rozważny wybór sojuszu i kierunku działań wojennych - ustalony na utajnionych naradach. Poparł konieczność fortyfikacji zamku w Lubowli, który był siedzibą jego starostwa grodowego, oraz Krakowa. Przy okazji podkreślił rolę króla, za co mu dziękował, za tzw. opatrzenie Lwowa, a całe wystąpienie skończył instancją za sukcesorami zmarłego dzierżawcy mennic królewskich Tytusa Liwiusza Borattiniego. Mowa Lubomirskiego była zatem pełna frazesów, ale i asekurancka, marszałek dał w niej bowiem świadectwo popierania programu królewskiego w aspekcie wzmocnienia obrony Krakowa oraz swojej spiskiej Lubowli, podkreślając tu zagrożenie ze strony Węgrów (tj. kuruców) oraz samych Turków.

Po wotach senatorskich porządek dzienny obrad został zdominowany przez sprawy prywatne, co, zdaniem Kazimierza Konarskiego, oznaczało poważne obniżenie poziomu merytorycznego sejmowania ${ }^{4}$. Nie ma dowodów, czy poruszanie spraw drugorzędnych w stosunku do kwestii zagrożenia państwa wynikało tylko z partykularyzmu lokalnego, czy było napędzane przez opozycję, aby odkładać w nieskończoność zawarcie traktatu zaczepno-odpornego z cesarzem. Nawet jeśli były to wyłącznie partykularyzmy lokalne, to na pewno były one po myśli środowiska politycznego marszałka wielkiego. Dwór królewski był jednak dobrze przygotowany do rozprawy z opozycją. We wtorek I6 marca w izbie senatorskiej odczytano list polskiego rezydenta w Stambule Samuela Proskiego, „w którym oznajmuje o wielkiej Turków gotowości na wojnę, dając przestrogi, że nie tylko przeciwko cesarzowi chrześcijańskiemu myślą, ale się grożą i przeciwko nam”ł². Dwór, potęgując atmosferę strachu w związku z możliwą inwazją turecką, stworzył wrażenie, że każdy przeciwny sojuszowi z cesarzem i podjęciu działań przeciw Porcie działa na szkodę państwa. W tym momencie nastąpiła ofensywa przeciw opozycji. Wystąpienie rozpoczął podkanclerzy J. Gniński, który oznajmił, że Rzeczpospolita nie przygotuje się do odparcia zagrożenia, póki nie uspokojone zostaną „wewnętrzne difidencyje”. Tu ujawnił przejętą i częściowo zaszyfrowaną korespondencję posła (ambasadora) francuskiego Françoise'a L'Hôpital de Vitry, w której były sugestie, aby przygotować się do nowej elekcji z potencjalnymi kandydatami do tronu polskiego w osobach niedawno nominowanych hetmanów wielkich - koronnego Stanisława J. Jabłonowskiego i litewskiego Kazimierza Jana Sapiehy lub marszałka Lubomirskiego. Potem zaatakowany został podskarbi Morsztyn, że to on był głównym wykonawcą polityki Ludwika XIV w Polsce, albowiem ,sejmiki partykularne in favore króla francuskiego porwał

\footnotetext{
40 Diariusz sejmu..., s. 15. Analizę różnych mów sejmowych S.H. Lubomirskiego zob. A. Karpiński, Mowy i rozmowy Stanisława Herakliusza Lubomirskiego, w: Kultura słowa żywego w dawnej Polsce, red. H. Dziechcińska, Warszawa 1989, s. 156-182.

${ }^{41}$ K. Konarski, op. cit., s. 127; J. Stolicki, Wobec wolności..., s. 253.

42 Diariusz sejmu..., s. 42-43; J. Stolicki, Wobec wolności..., s. 254-255.
} 
i sejm jakoby obiecywał rozerwać mając już na to kilku posłów kupionych”ł3. Dowodem na działalność Morsztyna miała być ujawniona przez Gnińskiego zaszyfrowana korespondencja podskarbiego z królem francuskim. Skompromitowanie Morsztyna było bez wątpienia punktem zwrotnym w rozgrywce sejmowej. Sam marszałek Lubomirski znalazł się wówczas w trudnej sytuacji. Jako sugerowany kandydat do korony, stał się w opinii publicznej winny spisku. Był ponadto pomówiony o branie pieniędzy z Francji i prowadzenie korespondencji z Ludwikiem XIV. Tu marszałek bronił się, że napisał do króla francuskiego, iż chciał tylko posłować do Turcji, najlepiej wraz z przywódcą kuruców Imre Thököly, a i nie utrzymywał z Ludwikiem XIV innych traktatów i korespondencji ${ }^{44}$. W tej sytuacji zmuszony był razem z, bądź co bądź, przyjacielem i stronnikiem króla - Jabłonowskim, do złożenia kurtuazyjnej deklaracji, że razem są gotowi stanąć przed sądem i dowieźć swojej niewinności ${ }^{45}$. Jak się okazało, rozładowało to nastroje społeczeństwa oraz uspokoiło króla. W ten sposób, jak już podkreślano w historiografii, Lubomirski poświęcił sprawę podskarbiego w imię własnego dobra. Sam Morsztyn nie miał już możliwości obrony, ponieważ działania wymierzone przeciw niemu ukształtowały opinię publiczną po myśli dworu ${ }^{46}$.

Cała akcja polityczna wymierzona w Morsztyna i stronnictwo profrancuskie zmusiła marszałka wielkiego do zmiany postawy. Niewątpliwie Lubomirski stracił wówczas wizerunkowo, dlatego jego następne posunięcia nastawione były na odbudowanie nadszarpniętego autorytetu. W wymiarze deklaracji politycznych wyzbył się obiekcji wobec sojuszu Rzeczypospolitej z Cesarstwem, co wyraził złożeniem podpisu pod polsko-austriackim traktatem zaczepno-obronnym z I kwietnia I683 r. (antydatowanym na 3I marca) ${ }^{47}$. Następnie zaangażował się w kwestie natury militarnej poprzez zaciągi wojskowe na potrzeby uchwalonego komputu wojennego w Koronie, funkcjonującego od I maja. Lubomirski, w przeciwieństwie do braci Hieronima Augustyna czy zmarłego w I675 r. Aleksandra, nie był nigdy faktycznym oficerem wojska koronnego $0^{4}$, ale posiadał pewne zasługi jako osoba utrzymująca w kompucie swoje jednostki. W okresie pokoju I677-I683 marszałek wielki dysponował chorągwią pancerną w sile 60 koni, która od I679 r. znajdowała się w repartycji województwa sandomierskiego. Strukturalnie wchodziła ona w skład pułku jazdy brata marszałka - Hieronima Augustyna. Oprócz niej, w skład komputu koronnego wchodziła

43 Diariusz sejmu..., s. 43; J. Stolicki, Wobec wolności..., s. 255.

44 Z Warszawy, 14 III 1683, w: Akta do dziejów..., s. 54.

45 Diariusz sejmu ..., s. 46. J. Stolicki (Wobec wolności..., s. 255, przyp. 182) podaje mylną informację, że Jabłonowski chciał stanąć przed sądem razem z Sieniawskim, albowiem diariusz sejmu wyraźnie wskazuje marszałka wielkiego, a nie dawnego już marszałka nadwornego. O ówczesnej postawie Sapiehów, w tym Kazimierza Jana również pomówionego o udział w spisku zob. M. Sawicki, Dom sapieżyński 1666-1685. Droga do hegemonii w Wielkim Księstwie Litewskim, Opole 2016, s. 218-220; А. Каменскі, Сапегі у дачьіненнях з БрандэнбургамПрусіяй у 1674-1696 г2., „Arche”, 3 (148)/2016, s. 18-20.

46 Świetnie podsumował ten stan rzeczy K. Konarski (op. cit., s. 130): „Wszyscy ostentacyjnie zrywali wszelkie dalsze stosunki z podskarbim. Charakterystycznym jest fakt, że podczas gdy przemówienie Morstina z tak namiętną spotkało się opozycją, to usprawiedliwienia późniejszych mówców wprost z entuzjazmem. Najgoręcej oklaskiwał je pono sam król”. Zob. ponadto: K. Matwijowski, W. Roszkowska, op. cit., s. 47; J.A. Gierowski, op. cit., s. 17-18; J. Wimmer, Wiedeń 1683 ..., s. 138-139; J. Stolicki, Wobec wolności..., s. 255.

47 Foedus offensivum et defesivum inter Leopoldum Imp. Rom. Hungariae, et Bohomiae Regem, et Johannem III. Regem et Regnum Poloniae, Magnumque Ducatum Lituaniae initum, quo pro mutua securitate societas Armorum contra Turcas constituitur, Warszawa, 31 III 1683, w: Akta do dziejów..., s. 66. Pełne omówienie: J. Wimmer, Wiedeń $1683 \ldots$... s. 140-142.

48 Z. Hundert, Działalność wojskowa ..., s. 386-387. Pominąłem tu casus przyrodnich braci Stanisława Herakliusza - Franciszka Sebastiana i Jerzego Dominika, którzy z wojskiem związali się dopiero w latach 80. 
też piechota starościńska Lubomirskiego w trybie węgierskim (50 porcji), która obsadzała zamek w Lubowli. Od I679 r. dotowana była przez sejmik proszowicki województwa krakowskiego ${ }^{49}$. Ten stan posiadania uległ zmianie w związku z decyzjami sejmu I683 r. Na naradzie posejmowej 5 maja marszałek Lubomirski zdeklarował się wystawić na potrzeby kampanii wojennej chorągiew husarską i 400 porcji piechoty $5^{\circ}$. W praktyce deklaracje te uległy pewnym modyfikacjom, ponieważ Lubomirski wystawił regiment pieszy w sile 280, a nie 400 porcji; chorągiew husarską odstąpił mu natomiast podstoli koronny Stefan Grudziński. Marszałek wielki powiększył ją jedynie z 80 koni w starym zaciągu do I20 w nowym. Podobnie, Lubomirski objął 6o-konną rotę wołoską zmarłego latem I682 r. kasztelana krakowskiego i hetmana wielkiego koronnego Dymitra Wiśniowieckiego, która weszła do służby w maju I683 r. w sile 80 koni. Te wszystkie 3 oddziały znalazły się na liście płac województwa sandomierskiego, a więc obszaru silnych wpływów politycznych i ekonomicznych marszałka wielkiego. Oprócz nich, Lubomirski w dalszym ciągu miał do dyspozycji załogę zamku w Lubowli, która od I683 r. miała być opłacana w sile Ioo porcji przez województwo krakowskie. W stosunku do okresu sprzed I683 r. marszałek wielki nie dysponował już chorągwią pancerną, przekazał ją bowiem swojemu młodszemu, przyrodniemu bratu - Franciszkowi Sebastianowi, staroście olsztyńskiemu ${ }^{51}$.

Lubomirski jako jeden z najważniejszych polityków tego okresu był po sejmie I683 r. pod presją społeczną, dlatego nie dziwi, że zaangażował się w kwestie zaciągów wojskowych na potrzeby zbrojnej rozprawy z Wysoką Portą. Miało to swoje znaczenie nie tylko w aspekcie czysto militarnym, ale także prestiżowym. Przy tej okazji warto nadmienić, że to właśnie w epoce sejmu I683 r. i przygotowań do kampanii wiedeńskiej marszałek wielki opublikował drukiem bodaj najważniejsze ze swoich dzieł - Rozmowy Artaksesa i Ewandra. Część tej rozprawy, poświęcona sprawom wojskowym, dowodzi, że Lubomirski był świetnie zorientowany w problematyce polskiej wojskowości omawianego okresu ${ }^{52}$ a to mogło mieć przełożenie na jakość przygotowań własnych jednostek na kampanię wiedeńską.

\footnotetext{
49 Idem, Wykaz koronnych choragwi i regimentów w okresie 1 V 1679 - 30 IV 1683. Przyczynek do organizacji wojska koronnego w dobie pokoju 1677-1683, w: Studia Historyczno-Wojskowe, t. 5, red. M. Nagielski, K. Bobiatyński, P. Gawron, Zabrze - Tarnowskie Góry 2015, s. 283; idem, Dyslokacja partii wojska koronnego w 1677 roku. Przyczynek do badań pogranicza polsko-tureckiego oraz organizacji armii w dobie pokoju 1677-1683, „Klio: Czasopismo poświęcone dziejom Polski i powszechnym”, 2016, nr 1 (36), s. 45, 54; idem, Wykaz repartycji jednostek wojska koronnego, zgodnie z podziatem komisji lwowskiej w 1679 roku, „Przegląd Historyczno-Wojskowy”, 17 (58)/2016, z. 2-3 (256-257), s. 25, 26.

${ }_{50}$ Relacja z narad posejmowych, Biblioteka XX. Czartoryskich w Krakowie (dalej: B. Czart.), rkps 426, s. 292; J. Wimmer, Wiedeń $1683 \ldots$, s. 159-160.

${ }_{51}$ Na podstawie: Likwidacja wojska JKM i Rzeczypospolitej polskiego i cudzoziemskiego zaciagu na trybunale skarbowym radomskim anni 1685 z repartycyjej sejmowej anni 1683 odprawiona, AGAD, ASK, dz. 86 (Akta Skarbowo-Wojskowe), sygn. 67; Rachunki sejmowe 1685 r., AGAD, ASK, dz. II, sygn. 68, k. 11-19; Komput wojsk JKM i Rzptej polskiego i cudzoziemskiego zaciagu, starego i nowego, podlug ordynacjej Rzptej na sejmie anni 1683 uczynionej i postanowionej, B. Czart., rkps 2563, s. 9-17; Podziat wojska JKM i Rzptej koronnego starego i nowego zaciagu ad proportionem podatków na sejmie anni 1683 uchwalonych na województwa i ziemie uczyniony, Warszawa 10 V 1683, ibidem, rkps 2656, s. 127-138; por. J. Wimmer, Materiały do zagadnienia liczebności i organizacji armii koronnej w latach 1683-1689, „Studia i Materiały do Historii Wojskowości”, 8/1962, s. 254-279; idem, Wiedeń 1683..., s. 219-228; Z. Hundert, Wykaz koronnych ..., s. 279-287.

52 S.H. Lubomirski, Rozmowy Artaxessa i Evandra, w których polityczne, moralne i naturalne uwagi zawarte wedle podanych okazyi tak jako mówione właśnie byty prawdziwie wyrażone sa spisane, [b.m.w.] 1683, rozmowa XIII: O uwadze wojennej albo roztropnej odwadze. W wydaniu krytycznym zob. idem, Rozmowy Artaksesa i Ewandra, oprac. J. Dąbkowska-Kujko, Warszawa 2006, s. 237-250.
} 
Ze względu na spacyfikowanie przez dwór fakcji francuskiej, można uznać, że Lubomirski na sejmie I683 r. poniósł polityczną porażkę. Niemniej, z rozgrywki króla z opozycją wyszedł dość obronną ręką i odniósł nawet korzyści. Przede wszystkim, na sejmie pozytywnie zostały rozpatrzone jego sprawy, które w swej instrukcji wnosiła ziemia warszawska. Po pierwsze, powiększona została załoga Lubowli, choć nie do postulowanych w instrukcji I20, a do IOO ludzi; po drugie, Lubomirski mocą konstytucji sejmowej otrzymał w dziedziczne władanie królewską wieś Jazdów (Jazdowa/Ujazdów). Decyzja została umotywowana ,instacyją całego generału obywatelów Księstwa naszego Mazowieckiego, tudzież z respektu osobliwego na zasługi wielm. Stanisława Lubomirskiego, marszałka naszego wielkiego koronnego"s3. Na tym nie koniec profitów, albowiem za takowy należy uznać awans urzędniczy brata Stanisława - Hieronima Augustyna, dokonany podczas sejmu. Po tym, jak M.H. Sieniawski otrzymał buławę polną i ostatecznie województwo wołyńskie, marszałkiem nadwornym został dotychczasowy chorąży koronny i kawaler maltański. Urząd deklarowano mu 8 lutego ${ }^{54}$, w następstwie czego I2 marca dokonała się uroczysta nominacja. Laskę nadworną wręczał młodszemu Lubomirskiemu nie kto inny jak marszałek wielki. Wygłaszając z tej okazji mowę, Stanisław Herakliusz oznajmił już na wstępie: „Niech się nikt nie dziwuje, że rodzeni dwaj bracia rząd i majestat na jednej wspierają się lasce" ${ }^{55}$. Niewątpliwie nominacja Hieronima Augustyna na marszałkostwo nadworne była dla S.H. Lubomirskiego korzystna, relacje rodzinne mógł on bowiem wykorzystać do zwiększenia swego wpływu na działalność całego urzędu marszałkowskiego. Równie istotna była tu symbolika. Zdaniem kawalera de Beaujeu, Sobieski, mając na względzie fakt pozbawienia laski wielkiej koronnej Jerzego Sebastiana, ,pragnąć spełnić akt sprawiedliwości oddał rodowi Lubomirskiemu urząd najwyższy w kraju. Najstarszy syn banity został wielkim marszałkiem, a w kilka lat później, gdy zawakował urząd marszałka [nadwornego] koronnego, oddano go bratu tegoż księcia Lubomriskiego, król zaś łaskawie oświadczył, że zamiast jednej wielkiej laski odebranej domowi tegoż, oddaje dwie laski synom nieszczęśliwego banity"56. W ten sposób polityka nominacyjna króla mogła zostać poczytana przez społeczeństwo szlacheckie za akt „,dziejowej sprawiedliwości”, wzmacniając tym samym pozytywny wizerunek władcy. Nominacja dla Hieronima Augustyna była przede wszystkim nagrodą za jego dotychczasowe zasługi dla państwa oraz dworu, w tym zachętą do dalszych poświęceń, dopiero w następnej kolejności - metodą na pozyskanie przychylności marszałka wielkiego.

Stanisław H. Lubomirski po sejmie I683 r. potrzebował niewątpliwie wyciszenia i odpoczynku, zwłaszcza że jeszcze w czerwcu król uderzył w kompetencje jego urzędu. Jan III podjął wówczas próbę podważenia pozycji sądów marszałkowskich jako najwyższej instancji

\footnotetext{
53 Konstytucje sejmu 1683 r., w: Volumina Legum, t. 5, oprac. J. Ohryzko, Petersburg 1860, s. 329; J.A. Gierowski, op. cit., s. 18. Konstytucja odwołuje się do uchwał generału mazowieckiego, a nie samej ziemi warszawskiej, ponieważ na sejmiku generalnym 26 I 1683 postanowiono, że posłowie z województwa mazowieckiego będą popierać wszystkie punkty instrukcji wyrażone w instrukcjach mazowieckich sejmików partykularnych. Tym samym postulaty Warszawian stały się postulatami całego generału mazowieckiego; zob. Uchwały generału mazowieckiego, Warszawa, 26 I 1683, B. PAU/PAN Kraków, rkps 8334, k. 233-235.

54 Zob. Diariusz sejmu..., s. 11; K. Konarski, op. cit., s. 125; J. Wimmer, Wiedeń 1683 ..., s. 135.

55 Oddawanie laski przez jmp. marszałka w. koron. jmp. rodzonemu swemu jmp. marszałkowi nadwor. koron. na sejmie w Warszawie dnia 13 marca roku 1683, B. PAU/PAN Kraków, rkps 1077, s. 41-44; por. Oddawanie laski nadwornej jmp. chorążemu koronnemu, staroście sądeckiemu, przez jmp. marszałka wielkiego koronnego, rodzonego jmści, od tronu JKM w sena[cie], ЛННБУ, F. 141 (Zbiór Czołowskiego), op. 1, rkps 53, s. 6-7.

${ }_{56}$ Pamiętniki kawalera de Beaujeu..., s. 205-206.
} 
i wprowadzenia tu instytucji apelacji nadzwyczajnej. W tym celu wykorzystał sprawę zabójstwa w ogrodach posiadłości podkanclerzego J. Gnińskiego niejakiego Samuela Jarmulskiego. Rodzina zabitego miała wnieść nadzwyczajną apelację, ponieważ osoby pozwane o to zabójstwo sąd marszałkowski zamierzał uniewinnić, a marszałek nie dopilnował wszystkich procedur nakładanych przez prawo - co też stało się formalną podstawą apelacji. Nie znany jest finał tej sprawy, niemniej była ona na pewno poważnym ostrzeżeniem dla Lubomirskiego i być może reakcją dworu na dotychczasową opozycyjną działalność marszałka. Jeśli król wypracowałby tu metody na ograniczenie kompetencji sądów marszałkowskich, odebrałby Lubomirskiemu ważny instrument działalności politycznej. Do tego jednak nie doszło, a marszałek wielki w przyszłości zachowywał więcej ostrożności ${ }^{57}$. Zresztą, sam król, zajęty wówczas przygotowaniami do kampanii wiedeńskiej, poprzestał w czerwcu I683 r. tylko na ostrzeżeniu marszałka wielkiego i już raptem kilka dni później znów wyciągnął do niego rękę w postaci wystawienia dokumentu z potwierdzeniem donacji rodziny Lubomirskich na rzecz kościołów katolickich ${ }^{8}$.

Aktywność polityczna marszałka w dalszych miesiącach 1683 r. słabła. Nie wziął np. udziału w radzie senatu z 8 sierpnia, bezpośrednio poprzedzającej wymarsz władcy w kierunku oblężonej stolicy cesarskiej. Zresztą, zgodnie z zachowanymi protokołami z Archiwum Zamoyskich, pierwsza rada senatu po sejmie I683 r., w której Lubomirski uczestniczył, odbyła się w lipcu następnego roku w Żółkwi ${ }^{59}$. Sprawy polityczne w drugiej połowie I683 r. mniej zajmowały marszałka, aczkolwiek nie omieszkał on napisać listów do Jana III z gratulacjami za sukcesy odniesione w działaniach wojennych ${ }^{60}$. Był przy tym cały czas postrzegany jako kluczowy gracz na polskiej scenie politycznej, dlatego kierował do niego list sejmik opatowski, w sprawie ujęcia Morszyna - co było już wcześniej omawiane, a także w dniu 26 grudnia przywódca kuruców - I. Thököly, nadając wówczas list także do Jana III ${ }^{61}$.

Ocena postawy S.H. Lubomirskiego wobec sejmu I683 r. nie jest jednoznaczna, tak jak jednoznaczna nie była sama postać marszałka wielkiego, w której, jak w soczewce, skupiały się różnorodne sfery działalności publicznej. Z jednej strony doradzał królowi, jak zwiększyć efektywność pracy sejmu, z drugiej nie zależało mu na dojściu obrad I683 r. do skutku, ponieważ jego środowisko polityczne było przeciwne wojnie z Turcją, patrząc w kierunku wschodnim i biorąc garściami subsydia francuskie. Lubomirski, snując plany i knując intrygi, wykonywał sumiennie obowiązki urzędu marszałkowskiego i powinności senatora. Nie zapominał o prywatnych sprawach, aby otrzymać na własność Jazdów czy lepiej zabezpieczyć swoje dobra spiskie, wiedząc, że tu będzie miał błogosławieństwo stanów sejmujących, ze względu na strategiczne znaczenie Lubowli. W odpowiednim czasie teatralnie wyrzekł się

\footnotetext{
57 Jan III do S.H. Lubomirskiego, [Wilanów] 19 VI 1683, B. PAU/PAN Kraków, rkps 1077, s. 51-52; Reskrypt $w$ tejże materyi z Wilanowa 19 juny 1683, ibidem, s. 52-53. Więcej o tej sprawie zob. K. Wiśniewski, Urząd marszatkowski koronny..., s. 112.

58 Jan III do S.H. Lubomirskiego, Warszawa, 23 VI 1683, AGAD, Archiwum Lubomirskich z Małej Wsi (dalej: ALMW), sygn. 1633, s. 15-17.

59 Senatus consilium, pod Krakowem 8 VIII 1683, AGAD, AZ, sygn. 3046, s. 362-364; Senatus consilium, Żółkiew 26 VII 1684, ibidem, s. 387-390.

60 S.H. Lubomirski do Jana III, b.m.d.w. [XI lub XII 1683] i odpowiedź króla na ten list, Kraków, 11 I 1684 , B. PAU/PAN Kraków, rkps 1077, s. 55-56. Zob. też S.H. Lubomirski do Jana III, Warszawa, 4 X 1683, AGAD, ALMW, sygn. 1633, s. 23.

${ }^{61}$ I. Thököly do S.H. Lubomirskiego oraz do Jana III, z Tokaja, 26 XII 1683, B. PAU/PAN Kraków, s. 56-59. Lubomirski dał odpowiedź na ten list dopiero 15 III 1683 w Łańcucie (ibidem, s. 59-61).
} 
Morsztyna $^{62}$, a następnie poświęcił całą energię, aby zorganizować swoje jednostki wojskowe na potrzeby rozprawy z Portą Osmańską. Być może zdawał sobie sprawę, że król nie pójdzie z nim na pełną konfrontację, ponieważ posiadał pewne zabezpieczenie, jakim był brat Hieronim, bliski współpracownik dworu. Kluczowo nie zamierzał też trzymać się swych profrancuskich sympatii, albowiem niedługo potem wszedł w sojusz z dworem cesarskim, bynajmniej nie grając ze środowiskiem politycznym Jana III w jednej drużynie ${ }^{63}$. Okres sejmu I683 r. był zatem cenną lekcją dla marszałka wielkiego, a przy okazji też sprawdzianem, poprzez który Lubomirski dowiódł, iż należy go postrzegać jako zręcznego polityka, potrafiącego dostosować się do dynamicznie zmieniających się politycznych okoliczności i korzystać tu z szeregu systemowych oraz pozasystemowych środków.

\section{Stanisław Herakliusz Lubomirski, Grand Marshal of the Crown, Warsaw Sejm in 1683 and issue of Ottoman War Summary}

In 1683 Stanisław Herakliusz Lubomirski was one of the most important politicians in Polish-Lithuanian Commonwealth. He was part of anti-royal opposition, which was against alliance with Austria and war against Ottoman Empire. Lubomirski's letters date before Warsaw Sejm indicates that he supported war against Muscovy. During Sejm he fulfilled his role as Grand Marshal, but at the same time he worked towards French interests. When the king and his supporters managed to defeat political opposition, Lubomirski switched sides and claimed that he never supported the king's opponents. He then participated in signing a treaty with Austria and also enlisted few military units to take part in war against the Turks. After I683, Sejm - for the time being - limited his political activities. Despite political defeat, he managed to achieve some personal successes - became owner of the town of Jazdów (Ujazdów), while his brother Hieronim was nominated for the office of Crown Court Marshal.

Keywords: Stanisław Herakliusz Lubomirski, office of Crown Grand Marshal, Warsaw Sejm in I683, battle at Vienna I683, Polish-Ottoman War I683-I699

\section{BIBLIOGRAFIA}

Archiwalia i źródła rękopiśmienne

Archiwum Główne Akta Dawnych w Warszawie:

Archiwum Lubomirskich z Małej Wsi, sygn. I633.

Archiwum Publiczne Potockich, sygn. I63a (t. I5), 315.

Archiwum Skarbu Koronnego:

dz. II, sygn. 68.

dz. V, sygn. II.

\footnotetext{
62 Jak niedługo później informował królową Marię Kazimierę wojewoda lubelski i administrator skarbu koronnego Marcin Zamoyski, Lubomirski równie teatralnie wyparł się też swego udziału w spisku antykrólewskim z początku 1684 r.; zob. R. Kołodziej, Listy od Jej Mości Królowej. O próbach wplywania Marii Kazimiery na sytuację wewnętrzna w Rzeczypospolitej, w: Maria Kazimiera Sobieska (1641-1716). W kręgu rodziny, polityki i kultury, red. A. Kalinowska, P. Tyszka, Warszawa 2017, s. 107.

63 Stał się nawet zagorzałym stronnikiem cesarza; K. Matwijowski, W. Roszkowska, op. cit., s. 47-48; J.A. Gierowski, op. cit., s. 18 .
} 
dz. VI, sygn. 23 .

dz. 86 (Akta Skarbowo-Wojskowe), sygn. 67.

Archiwum Warszawskie Radziwiłłów, dz. II (publica), sygn. I7I9.

Archiwum Zamoyskich, sygn. 3046.

Biblioteka Polskiej Akademii Umiejętności i Polskiej Akademii Nauk w Krakowie, rkps I077, 8334, 8348.

Biblioteka XX. Czartoryskich w Krakowie, rkps 426, 2563, 2656.

Львівська Національна Наукова Бібліотека України імені Василя Стефаника, F. I4I (Zbiór Czołowskiego), op. I, rkps 53.

Źródła wydane

Akta do dziejów króla Jana III sprawy roku I683, a osobliwie wyprawy wiedeńskiej wyjaśniajace, oprac. F. Kluczycki, Kraków I883.

Lubomirski S.H., Rozmowy Artaxessa i Evandra, w których polityczne, moralne i naturalne uwagi zawarte wedle podanych okazyi tak jako mówione właśnie byty prawdziwie wyrażone sq spisane, [b.m.w.] I683.

Lubomirski S.H., Rozmowy Artaksesa i Ewandra, oprac. J. Dąbkowska-Kujko, Warszawa 2006. Pamiętniki kawalera de Beaujeu, tłum. A. Kraushar, oprac. W. Markowski, Kraków I883.

Stanisława Herakliusza Lubomirskiego mowy sejmowe z I670 i I673 roku oraz „Informacyja potrzebna bardzo Rzeczypospolitej I67I o prawie własnym i dziedzicznym, które ma Rzeczpospolita do Spisza i części ziemie węgierskiej, przeciwko pretensyjom Cesarza JM, tudzież jako wiele Rzeczypospolitej należy na utrzymaniu tego kraju”, oprac. K. Przyboś, red. A. Perłakowski, Kraków 2010.

Volumina Legum, t. 5, oprac. J. Ohryzko, Petersburg I860.

Opracowania

Gierowski J.A., Stanisław Herakliusz Lubomirski jako polityk, w: Stanisław Herakliusz Lubomirski. Pisarz - polityk-mecenas, red. W. Roszkowska, Wrocław - Łódź I982, s. 9-24.

Hundert Z., Dyslokacja partii wojska koronnego w I677 roku. Przyczynek do badań pogranicza polsko-tureckiego oraz organizacji armii w dobie pokoju I677-I683, „Klio: Czasopismo poświęcone dziejom Polski i powszechnym", 20I6, nr I (36), s. 4I-67.

Hundert Z., Działalność wojskowa i polityczna Hieronima Augustyna Lubomirskiego w latach I669-I673 - glosa do biografii, w: Hortus bellicus. Studia z dziejów wojskowości nowożytnej, red. K. Bobiatyński, P. Gawron, K. Kossarzecki, D. Milewski, P. Kroll, „Biblioteka Epoki Nowożytnej”, 5/20I7, s. 385-404.

Hundert Z., Pozycja Jana III w wojsku koronnym w latach I674-I683. Utrzymanie czy też utrata wplywów wypracowanych w czasie sprawowania godności hetmańskiej?, w: Król Jan III Sobieski i Rzeczpospolita w latach I674-I683, red. D. Milewski, Warszawa 20I6, S. I2I-I5I.

Hundert Z., Wykaz koronnych choragwi i regimentów w okresie I V I679- 30 IV I683. Przyczynek do organizacji wojska koronnego w dobie pokoju I677-I683, w: Studia Historyczno-Wojskowe, t. 5, red. M. Nagielski, K. Bobiatyński, P. Gawron, Zabrze - Tarnowskie Góry 20I5, s. 274-287.

Hundert Z., Wykaz repartycji jednostek wojska koronnego, zgodnie z podziałem komisji lwowskiej w I679 roku, „Przegląd Historyczno-Wojskowy”, I7 (58)/20I6, z. 2-3 (256-257), s. I7-34. 
Каменскі А., Сапегі ў дачьіненнях з Брандэнбургам-Прусіяй у I674-I696 г2., „Arche”, 3 (I48)/20I6, s. 8-37.

Karpiński A., Mowy i rozmowy Stanisława Herakliusza Lubomirskiego, w: Kultura słowa żywego $w$ dawnej Polsce, red. H. Dziechcińska, Warszawa 1989, s. I56-I82.

Koczegarow K., Rzeczpospolita a Rosja w latach I680-I686. Zawarcie traktatu o pokoju wieczystym, tłumaczenie z j. rosyjskiego, wyd. uzup. i popr., red. T. Szwaciński, Warszawa 2017.

Kołodziej R., ,, Ostatni wolności naszej klejnot”. Sejm Rzeczypospolitej za panowania Jana III Sobieskiego, Poznań 2014.

Konarski K., Polska przed odsiecza wiedeńska I683 roku, Oświęcim 2017 (reedycja wydania z I9I4 r.).

Kroll P., Jan III Sobieski wobec Kozaczyzny w latach I676-I683, w: Król Jan III Sobieski i Rzeczpospolita w latach I674-I683, red. D. Milewski, Warszawa 20I6, s. 2I7-226.

Matwijowski K., Roszkowska W., Lubomirski Stanisław Herakliusz (ok. I642-I702), w: Polski Stownik Biograficzny, t. I8, Wrocław 1973, s. 45-50.

Piwarski K., Hieronim Lubomirski. Hetman wielki koronny, Oświęcim 2015 (reedycja wydania z I929 r.).

Przyboś A., Gniński Jan (zm. I685), w: Polski Słownik Biograficzny, t. 8, Kraków I959, s. I49-I5I.

Sawicki M., Dom sapieżyński I666-I685. Droga do hegemonii w Wielkim Księstwie Litewskim, Opole 2016.

Skórska-Jarmusz A., Stanisław Herakliusz Lubomirski-starosta spiski, „Rocznik Sądecki”, 34/2006, s. 62-86.

Stasiewicz K., W kręgu polityki i literatury: źródła i studia o Stanisławie Herakliuszu Lubomirskim, Olsztyn 2016.

Stolicki J., Propaganda antyturecka w latach I676-I683, w: Król Jan III Sobieski i Rzeczpospolita w latach I674-I683, red. D. Milewski, Warszawa 20I6, s. I9-33.

Stolicki J., Rozdawnictwo wakansów przez Jana III jako metoda tworzenia partii dworskiej, w: Faworyci i opozycjoniści. Król a elity polityczne w Rzeczypospolitej XV-XVII wieku, red. R. Skowron, M. Markiewicz, Kraków 2006, s. 359-375.

Stolicki J., Wobec wolności i króla. Działalność polityczna szlachty ruskiej, ukrainnej i wotyńskiej w latach I673-I683, Kraków 2007.

Urzędnicy dawnej Rzeczypospolitej XII-XVIII wieku. Spisy, red. A. Gąsiorowski, t. Io: Urzędnicy centralni i nadworni Polski XIV-XVIII wieku. Spisy, oprac. K. Chłapowski et al., Kórnik 1992.

Wierzbicki L.A., O zgodę w Rzeczypospolitej. Zjazd warszawski i sejm pacyfikacyjny I673 roku, Lublin 2005.

Wimmer J., Materiały do zagadnienia liczebności i organizacji armii koronnej $w$ latach I683-I689, „Studia i Materiały do Historii Wojskowości”, 8/I962, s. 243-279.

Wimmer J., Wiedeń I683. Dzieje kampanii oraz bitwy, Warszawa I983.

Wiśniewski K., Działalność marszałka wielkiego koronnego Stanisława Herakliusza Lubomirskiego w bezkrólewiu po śmierci Jana III, „Rocznik Warszawski”, 30/200I, s. I3-52.

Wiśniewski K., Urząd marszałkowski koronny w bezkrólewiach XVII-XVIII wieku (I632I736), Warszawa 2015. 